\title{
Participation of Prison Inmates in Vocational Skills Acquisition Programmesfor Self- Reliance and Sustainable Economic Growth in SokotoState, Nigeria
}

\author{
Kulu, HARUNA ABUBAKAR ${ }^{1} \&$ Mannir ABBA $^{1}$ \\ ${ }^{1}$ Department of Adult Education and Extension Services, Usmanu Danfodiyo University, Sokoto, Nigeria \\ 2 Department of Adult Education and Extension Services, Usmanu Danfodiyo University, Sokoto, Nigeria \\ Correspondence: Mannir ABBA, Mannir Abba, Department of Adult Education and Extension Services, Usmanu \\ Danfodiyo University, Sokoto, Nigeria.
}

Received: March 29, 2017 Accepted: April 5, 2017 Online Published: March 12, 2018

doi:10.5539/res.v10n2p37 URL: https://doi.org/10.5539/res.v10n2p37

\begin{abstract}
The study focused on assessing the extent of participation of prison inmates in vocational skills acquisition programmes in SokotoState. The main objective of the study was to assess the extent of participation of prison inmates in vocational skills acquisition programmes for self - reliance and sustainable economic growth in SokotoState. One research question and one null hypothesis guided the study. A survey research design was adopted for the study. The population of the study was 1226 respondents at the time of the study. The sample size of the study was 351 comprising all the 85 prison officials and 266 convicted prisoners of the Sokoto central prison deliberately selected for the study. The instrument used for data collection was self-structured questionnaire tagged "Questionnaire on the participation of prison inmates in vocational skills acquisition programmes (QPPIVSAP). The instrument was subjected to face validation by three experts. The reliability coefficient for the instrument was 0.80 . The data collected was analysed using descriptive statistics of mean and standard deviation, while the null hypothesis was tested using t-test at the probability of 0.05 level of significance. The findings of the study revealed that VSA programmes for prison inmates were only found available in Sokoto Central Prison and there were prison inmates trainees in the prison. The findings further revealed that the trainees participated in the available VSA programmes to a high extent in the study area. Based on these findings, the study recommended among others that the Nigerian Prisons Service (NPS) should extend the VSA programmes to other convict and satellite's prisons for inmates' self - reliance and sustainable economic growth of the state and the country at large. The NPS should introduce more vocational trades that are not available in the prisons. Such as electrical and electronics repairs, graphic arts, shoe making and automobile mechanic skills acquisition programmes while the prison inmates should be encouraged to patronize the programmes for their self-reliance and sustainable economic growth of the society.
\end{abstract}

Keywords: Vocational Skill Acquisition Programmes, Prison inmates, Economic Growth

\section{Introduction}

The Nigerian Prisons Service (NPS) is constitutionally responsible for ensuring the safe custody of offenders as well as their reformation, rehabilitation and re-integration. Dambazau (2007) noted that the rationale for imprisonment is evident in decree No. 9 of 1972 which assigned the prisons with the responsibility among others to teach and train the prisoners to become useful and law abiding citizens on discharge. These responsibilities are discharged through carefully designed and well-articulated administrative, reformative and rehabilitative programmes aimed at inculcating discipline, respect for law and order, and the dignity of honest labour (Igbo, 2007). The offender, in this wise, is prepared to become not only law abiding but also useful to both himself and the society at the expiration of his sentence. The Rule 71 (3) of the United Nations' Standard Minimum Rules for the Treatment of Prisoners (UNSMRFTP) stated that "sufficient work of a useful nature shall be provided to keep prisoners actively employed for a normal working day" (Tenibaije, 2010). Despite the UNSMRFTP, Nigeria still remains among the nations of the world that are rated with high rates of crime, poverty, unemployment, and recidivism among ex-prisoners (Abba and Mbagwu, 2016).

There are several obstacles that prison inmates may face upon their release from prison, including the prospect of unemployment. A lower level of educational attainment and a lack of vocational skills can hinder efforts to find a job and make a decent wage among prisoners upon their release from prison. According to Abba (2016), the major factors associated with offending and recidivism among ex-prisoners in SokotoState are poor employment prospects, weak skills 
and low education levels among others. Discharged prisoners in SokotoState are unemployed and sometimes stigmatized and treated as social pariahs. These social problems among ex-prisoners and rejection against them by the society, sometimes forces them back to crime and lead to their recidivism. Prison inmate in question can be conceptualized as adult person kept in a conformed institution such as prison or a mental hospital. It is another name given to a prisoner or an offender or violator of law. In the words of Abba (2016), prison inmate can be seen as a person who is kept in a confined place known as the prison, as an accused or convicted of violating the criminal law. Hence, in the context of this study, prison inmate can be seen as a person legally confined in an institution designed to securely house and rehabilitate people who are convicted of crime or on awaiting trial. These individuals known as prisoners or inmates are kept in continuous custody on a short or long-term basis. Individuals who commit the most heinous crime are sent to prison for more years, the more serious the offence, the longer the prison term imposed. For Davis, Jennifer and Robert (2014), they believed that providing vocational skills training to prison inmates while they are in prison can help them overcome these challenges by fostering the skills needed to find employment and enhance economic development in a society.

From the foregoing, vocational skills acquisition programmes could be regarded as the aspect of education that gives the recipients an opportunity to acquire practical skills as well as some basic knowledge which fits the individual for gainful employment in a recognised occupation as semi-skilled worker, technician or sub-professional. According to Onweonye, Obinne and Odu (2013), vocational training in prison is considered essential for the achievement of the purpose of reformation, rehabilitation and reintegration of discharged prisoners. Reformation and rehabilitation are the current issues that are central to modern penal-thinking and practices and have been adopted and implemented in some Nigerian prisons using vocational training.

Vocational training can be described as any form of educational activity whose primary purpose is to prepare beneficiaries to acquire skills for gainful self-employment, self-sufficiency and poverty alleviation. Vocational training in the word of Olaitan (2008) is a form of education that primarily concerns the development of occupational skills needed by an individual as a preparation for work. Vocational training according to Davis et al (2014), can be offered in various trade industries, including barbering, building maintenance, carpentry, electrical trades, painting, plumbing, horticulture, custodial maintenance, upholstery, auto detailing, masonry, welding, and heating, ventilation, and air conditioning. The type of vocational skills acquisition programmes available in a prison will depend on inmates' interests, availability of teaching staff, and funding. It is worth mentioning that the available VST programmes in most Nigerian Prisons according to Talba (2015) include agro-based skills acquisition, carpentry and joinery work, dress making, hair dressing, knitting, laundry and dry cleaning services, metalwork, soap and pomade making skills acquisition programmes. This is to enable prison inmates acquire skills especially in the area of arts and craft and to become self-reliant after their jail term and to keep them away from re-entry into prison in the near future.

The primary goal of vocational skills acquisition programme in prisons is to help offenders develop marketable job skills upon release to the community. Certificates or college credit can be earned for some vocational programmes in prisons. Hence, for this study, vocational skills training programme is any form of educational programme whose primary purpose is to prepare prison inmates for employment in recognized occupations after their jail term.

The prison in question has been a subject of debate among various scholars in the social science discipline. The concept has been treated from various perspectives, which include structural and functional dimensions. For instance, Abba and Mbagwu (2016) described a prison as a physical structure in a geographical location where a number of people living under highly specialized condition adjust to the alternatives presented to them by the unique kind of social environment. Similarly, Ogwuoke and Ameh (2014) conceived prison as a place where people are highly secluded from the rest of the world with entirely new order of control. The above conceptualizations as advanced by scholars are limited towards an understanding that a prison is a physical environment, and could be described geographically or spatially. Quite different from the physical conception, there are other schools of thought that are based on function, framework and label. From the functional perspective, a prison is perceived as a place to punish offenders, where criminals that are removed from the society are dumped to protect the society from further criminal activities of the offenders: and a place to rehabilitate, and teach offenders to be law abiding and productive after their release.

Prisons are also perceived as a total institution, from the perspective of framework, Okunola (2008) and Goffman (2006) variously defined the concept in this manner. Prison is an institution or a walled place unlike free environment or community that houses those who are socially rejected, insane or mentally retarded. Goffman (2006) on the other hand conceptualized total institution as where there is a basic split between a large class of individuals who are restricted to contact with outside world and stereotypical behavioral pattern where social mobility is restricted. Yet from the labelling point of view, the prison is a place for vagrants, who may pose actual danger to social life in the larger society, which pre-supposes that every person in the prison is a vagrant and irresponsible person. Meanwhile, Ogwokhademhe, Bolusteve and Adebayo (2014) defined prison as a place delineated and declared by the law of the state to ensure restraint and custody of individuals accused or convicted of violating the criminal laws of the state. 
Economic growth has been called "the science of how people make a living."According to Adewole (2012), economics is a study of man in the ordinary business of life. It enquires how he gets his income and how he uses it. While economic growth can be defined as continual changing of situation involving both multipliers and accelerators (Onisanwa, 2014). According to Rutherford (2002), economic growth is the growth in the total output of an economy often measured by an increase in the real gross net product (GNP) and caused by an increase in the supply of factors of production or their productivity. This is the rate at which a country's national income grows, usually shown as an increase in GDP or GNP or an increase in per capital income.

\subsection{Statement of the Problem}

It is evident from the background that reformation and rehabilitation are the current issues central to modern penal-thinking. For the purpose of actualizing the objectives of the NPS in terms of rehabilitation of prison inmates, VSA programmes were established in some Nigerian Prisons. Considering the fact that literature shows that there are VSA programmes available for the rehabilitation of prison inmates in some Nigerian prisons SokotoState inclusive as well as the country's current struggle for actualising it economic growth goal, actualising this target goal requires participation of every citizen prison inmates inclusive in the State and the country at large. Regrettably, despite the existence of the VSA programmes, the rate of crimes and recidivism among ex- prisoners is on the increase in the State. Sadly, there is presently inadequate information on the extent to which prison inmates participate in VSA programmes in SokotoState. Hence, the need for this study which seeks to assess the extent of participation of prison inmates in vocational skills acquisition programmes for self-reliance and sustainable economic growth in SokotoState. Any attempt to assess the extent of participation of prison inmates in VSA programmes must require gathering of information using various methods to systematically identify the areas and the level of participation of prison inmates in VSA programmes in the State. Thus, this study will provide information on the extent of participation of prison inmates in VSA programmes for self-reliance and sustainable economic growth in SokotoState, Nigeria.

\subsection{Review of Materials Related to this Study}

Asokhia and Osumah (2013) carried out a study titled "assessment of rehabilitation services in Nigerian Prisons in Edo State". The study adopted a descriptive survey research design. The population of the study consisted of 731 prison inmates in the six prisons of the State. Using stratified random sampling technique, a total of 147 respondents were selected as a sample for the study. The instrument for data collection was a checklist titled "adopted rehabilitation services in Nigerian Prisons in Edo State (ARSNPESC)". The research data were analysed using simple percentage. Some of the major findings of the study revealed among others that adult prisoners participated in adult and remedial educational programmes and educational development project in the six prisons of the study area.

The study is related to this present study as they are both concerned with rehabilitation of inmates. However, both studies differ as Asokhia and Osumah study was on the assessment of rehabilitation services in Nigerian Prisons in Edo State and the programmes available in the prisons; while the present study assessed the extent of participation of prison inmates in vocational skills acquisition programmes for self-reliance and sustainable economic growth in SokotoState, Nigeria.

Abba (2016) carried out a study titled "Rehabilitation of Prison inmates through Vocational Skills Acquisition programmes as Perceived by Prison officials in the North-West States, Nigeria". Descriptive survey design was adopted for the study. The population of the study was 1,592 prison officials. The researchers used deliberate sampling technique to determine the sample size of 351 respondents. A 40 items questionnaire was the instrument used to elicit information from the respondents. The data were analysed using mean and standard deviation. Some of the major findings were that: prison inmates participated in VSA programmes and the programmes have enhanced socio-economic well-being of the inmates to a high extent in the study area. The study is related to the present study because both studies focused on vocational skills acquisition programmes for rehabilitation of inmates but differed from the former which assessed the rehabilitation of prison inmates through vocational skills acquisition programmes as perceived by prison officials in the North-West States, Nigeria while the present study was cantered on assessing the extent of participation of prison inmates in vocational skills acquisition programmes for self-reliance and sustainable economic growth in SokotoState, Nigeria. Omoni (2009) carried out a study titled "An Assessment of the Qualitative Education for Prisoners in Delta State, Nigeria". Descriptive survey design was adopted for the study. The population of the study consisted of all the 310 prison staff in the five prisons in Delta State: Agbor, Kwale, Ogwashi-Uku, Sapele and Warri, and 166 academic staff of the College of Education, Agbor making total of 476 respondents. The researchers used stratified random sampling technique to determine the sample size of 300 respondents for the study. The instrument for data collection for the study was a self-structured questionnaire, whereas the data was analysed using simple percentages and chi-square $\left(\mathrm{x}^{2}\right)$. The findings of the study revealed among others that there is no significant difference in the opinion between prison staff and academic staff of the College of Education, Agbor, on the adequacy of prisoners' vocational and formal education programmes. The findings also showed that the two groups agreed that prisoners need vocational and formal education. The study is related 
to this present study because both studies focused on educational programmes for rehabilitation of prison inmates but differed from the former which assessed the qualitative education for prisoners in Delta State, Nigeria while the present study was cantered on assessing the extent of participation of prison inmates in vocational skills acquisition programmes for self-reliance and sustainable economic growth in SokotoState, Nigeria.

Finally, Akpunne (2014) carried out a study on Access to Basic Needs as Correlate of Desire to Participate in Rehabilitation Programmes among Inmates of Nigerian Prisons. The study adopted a descriptive survey research design. The population of the study consisted of 631 prison inmates of Kirikiri medium security prison, Lagos State, Nigeria. The researcher used purposive sampling technique to determine the sample size of 230 respondents for the study. The instrument for data collection was a self-structured questionnaire titled "Questionnaire on Desire to Participate in Rehabilitation Test (QDPRT)". The data were analysed using inferential and descriptive statistics. The findings of the study showed that there is no correlation between quality and quantity of feeding and desire of inmates' to participate in rehabilitation programmes. There is a significant positive correlation between sanitary conditions and desire to participate in rehabilitation programmes among inmates of Nigerian prisons. Both studies are related in analytical tool used but differed in scope and the area of study.

\subsection{Purpose of the Study}

The general purpose of the study was to examine the participation of prison inmates in vocational skills acquisition programmes for self-reliance and sustainable economic growth in SokotoState. Specifically, the study sought to:

Ascertain the extent of participation of prison inmates in vocational skills acquisition programmes for self-reliance and sustainable economic growth in SokotoState, Nigeria.

\subsection{Research Question}

One research question guided the study: To what extent have prison inmates participated in vocational skills acquisition programmes for self-reliance and sustainable economic growth in SokotoState?

\subsection{Hypothesis}

One null hypothesis was formulated for the study and tested at 0.05 level of significance:

$\mathrm{H}_{01}$ : There is no significant difference between the mean ratings of the prison officials and Prison inmates on the extent to which prison inmates participated in vocational skills acquisition programmes for self-reliance and economic growth in SokotoState.

\section{Research Method}

The study adopted descriptive survey research design. Descriptive survey research design according to Nworgu, (2015), aims at studying a group of people or items by collecting and analysing data from a sample of the same group or items considered to be a representative of the entire population. This design is considered appropriate for this study because it helped in eliciting information from the respondents on the extent of participation of prison inmates in vocational skills acquisition programmes for self-reliance and sustainable economic growth in SokotoState. The study was conducted in the SokotoState command of the Nigerian Prisons Service. The population of the study was all the1,226 respondents, comprising 727Awaiting Trial Prisoners (ATPs), 286 Convicted Prisoners (CPs) and 213 Prison Officials (POs) of the five prisons in SokotoState at the time of the study. The rationale behind choosing Sokoto central prison was because, out of the whole available prisons in the State, VSA programmes for rehabilitation of prison inmates were only found in Sokoto central prison. However, even in the selected prison, the VSA programmes were majorly designed for convict prisoners. Therefore, the researchers deliberately used all the 266 CPs and 85 POs found available in the Sokoto central prison as the sample size of the study. This is also for the fact that the population is a manageable size to be used as a sample for the study.

The research instrument used for data collection was a self- structured questionnaire developed by the researchers titled, "Questionnaire on the participation of prison inmates in vocational skills acquisition programmes (QPAPIVSAP)". The use of self-structured questionnaire was considered necessary for the collection of data for the study. Because Nworgu (2015) noted that in structured questionnaire, the respondent is restricted to some response options. A question is asked and some response options are supplied. From these, the respondent is expected to pick any one that best suits his/her response. The responses of the respondents in the questionnaire were used to address the research question and hypothesis that guided the study. A - 4 points rating scale of Very High Extent (VHE), High Extent (HE), Low Extent (LE) and Very Low Extent (VLE) was used for addressing the research question. The instrument was face validated by three experts: two of the experts were from the department of Science and Vocational Education, Usmanu Danfodiyo University, Sokoto, and one from the department of Adult Education and Extra-Mural studies, University of Nigeria, Nsukka. The instrument consists of eight items based on the research question and hypothesis. 
The reliability of the instrument was ascertained through a trial test method. Thirty (30) copies of the research instrument were administered on 15 prison officials and 15 convicted prisoners of Katsina Central Prison, Katsina State who share the same characteristics with those in the study area but were not used for the study. Cronbach Alfa was used to ascertain the internal consistency of the questionnaire items. The overall reliability index was 0.85 which was deed high enough for the study. For the purpose of data collection for the study, a quantitative method of field survey was used in this study by the researchers. This was done with the aid of two research assistants from the prison officials and two from the prison inmates of the Sokoto central prison, making total of four research assistants for the study. The entire instruments was administered to the respondents and collected the same day and a hundred percent (100\%) rate of return was recorded.

The research question was analysed using mean and standard deviation. The mean benchmark for answering the research question was 2.5 criterion mean. This means that any item with a mean score of 2.5 and above was accepted while a mean score below 2.5 was unaccepted. T-test statistics was used to test the null hypothesis at 0.05 level of significance. In testing the null hypotheses, the probability associated with the t-value was used for taking decision. When the associated probability value is greater than 0.05 level of significance, the researchers accept the null hypothesis. Whereas when the associated probability value is less than 0.05 level of significance, the researchers rejects the null hypothesis.

\section{Results}

Table 1. Prison Locations and Population of the Study

\begin{tabular}{|c|c|c|c|c|c|c|c|c|c|c|c|}
\hline \multirow[t]{3}{*}{ S/No } & \multirow[t]{3}{*}{$\begin{array}{l}\text { Prison } \\
\text { Location }\end{array}$} & \multirow{2}{*}{\multicolumn{2}{|c|}{$\begin{array}{l}\text { Number } \\
\text { Awaiting Tr } \\
\text { Prisoners(ATP) }\end{array}$}} & \multirow{2}{*}{$\begin{array}{l}\text { of Total } \\
\text { rialA.T.P. }\end{array}$} & \multirow{2}{*}{\multicolumn{2}{|c|}{$\begin{array}{l}\text { Number } \\
\text { Convicted } \\
\text { Prisoners (CP) }\end{array}$}} & \multirow{3}{*}{$\begin{array}{l}\text { of } \begin{array}{l}\text { Total } \\
\text { C.P. }\end{array} \\
\end{array}$} & \multirow{3}{*}{\begin{tabular}{|l|} 
I No. \\
Prison \\
Officials \\
Males
\end{tabular}} & \multirow{3}{*}{$\begin{array}{l}\text { of No. } \\
\text { Prison } \\
\text { Prficials } \\
\text { (Females) }\end{array}$} & \multirow{3}{*}{\begin{tabular}{|l|l|} 
of Total \\
Prison \\
Officials \\
(POs)
\end{tabular}} & \multirow[t]{3}{*}{$\begin{array}{l}\text { Total } \\
\text { Responde-nts }\end{array}$} \\
\hline & & & & & & & & & & & \\
\hline & & Males & Females & & Males & Females & & & & & \\
\hline 1. & $\begin{array}{l}\text { Sokoto } \\
\text { Central } \\
\text { Prison }\end{array}$ & 502 & 66 & 568 & 240 & 26 & 266 & 75 & 10 & 85 & 919 \\
\hline 2. & $\begin{array}{l}\text { Bissalam } \\
\text { Prison Farm }\end{array}$ & & & & 65 & & 65 & 35 & & 35 & 100 \\
\hline 3. & $\begin{array}{l}\text { Gwadabawa } \\
\text { Satellite } \\
\text { Prison }\end{array}$ & 32 & 10 & 42 & & & - & 26 & 04 & 30 & 72 \\
\hline 4. & $\begin{array}{l}\text { Tambawal } \\
\text { Satellite } \\
\text { Prison }\end{array}$ & 26 & 06 & 32 & & & - & 30 & 04 & 34 & 66 \\
\hline 5. & $\begin{array}{l}\text { Wurno } \\
\text { Satellite } \\
\text { Prison }\end{array}$ & 32 & 08 & 40 & - & 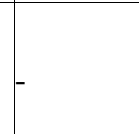 & - & 27 & 02 & 29 & 69 \\
\hline Grand & & & & & & & & & & & \\
\hline Total & 5 & 637 & 90 & 727 & 260 & 26 & 286 & 191 & 20 & 213 & 1226 \\
\hline
\end{tabular}

Source: Federal Ministry of Interior. (2017). 
Table 1 shows the total number of convicts' prisons, awaiting trial, convicted prison inmate and prison officials that were used for the study. The table also indicted that Sokoto Central Prison has 568 ATPs, 266 CPs and 85 POs; Bissalam Prison Farm has65 CPs and 35 POs; Gwadabawa Satellite Prison has 42 ATPs and 30POs. Tambawal Satellite Prison has 32 ATPs and 34 POs; While Wurno Satellite Prisonhas40 ATPs and 29 Pos respectively.

Table 2. Mean rating and standard deviation showing the extent to which prison inmates participated in vocational skills acquisition programmes for self-reliance and sustainable economic growth in SokotoState.

\begin{tabular}{|c|c|c|c|c|}
\hline S/No & Item & $\bar{x}$ & S D & Dec. \\
\hline 1 & Agro-based skills training & 2.53 & 0.91 & $\mathrm{HE}$ \\
\hline 2 & Carpentry and joinery work skills training & 2.68 & 0.85 & $\mathrm{HE}$ \\
\hline 3 & Dress making (tailoring) skills training & 3.23 & 0.75 & $\mathrm{HE}$ \\
\hline 4 & Hair dressing skills training & 2.66 & 0.87 & $\mathrm{HE}$ \\
\hline 5 & Knitting skills training & 2.56 & 0.93 & $\mathrm{HE}$ \\
\hline 6 & Laundry and dry cleaning services skills training & 3.32 & 0.74 & $\mathrm{HE}$ \\
\hline 7 & Metalwork skills training & 3.05 & 0.74 & $\mathrm{HE}$ \\
\hline \multirow[t]{2}{*}{8} & Soap and pomade making skills training & 2.68 & 0.84 & $\mathrm{HE}$ \\
\hline & Grand Mean and Standard Deviation & 2.84 & 0.35 & $\mathrm{HE}$ \\
\hline
\end{tabular}

Key: HE= High Extent and $\mathrm{N}=$ Number of Respondents

Table 2 above present the views of respondents on the extent to which prison inmates participated in vocational skills acquisition programmes for self-reliance and sustainable economic growth in SokotoState. From the results all the respondents on items 1 - 8 have mean ratings above the criterion level of 2.50 with their corresponding numerical values of standard deviations, and grand mean of 2.84 and SD of 0.35 . Since the mean ratings are above the criterion level of 2.50 for accepting an item, this confirms that the respondents agreed to a high extent that the prison inmates participated in vocational skills acquisition programmes for self-reliance and sustainable economic growth in SokotoState. 
Table 3.T-test analysis of the prison officials and inmates on the extent of participation of prison inmates in vocational skills acquisition programmes for self - reliance and sustainable economic growth.

\begin{tabular}{|c|c|c|c|c|c|c|c|c|}
\hline \multirow[b]{2}{*}{$\mathbf{S} / \mathbf{N}$} & \multirow[b]{2}{*}{ Item Statement } & \multirow[b]{2}{*}{$\begin{array}{l}\text { Respondent } \\
\text { s }\end{array}$} & \multicolumn{6}{|c|}{ Prisoners $=266$, Prison Officials $=85$} \\
\hline & & & $\overline{\bar{x}}$ & SD & t-cal & Df & Sig & Dec \\
\hline \multirow[t]{2}{*}{1} & \multirow[t]{2}{*}{ Agro-based skills training } & Prisoners & 2.56 & 0.90 & \multirow{2}{*}{1.20} & \multirow{2}{*}{349} & \multirow{2}{*}{0.23} & \multirow{2}{*}{ NS } \\
\hline & & Officials & 2.42 & 0.94 & & & & \\
\hline \multirow[t]{2}{*}{2} & \multirow[t]{2}{*}{ Carpentry and joinery work skills training } & Prisoners & 2.66 & 0.91 & \multirow{2}{*}{-1.37} & \multirow{2}{*}{349} & \multirow{2}{*}{0.17} & \multirow{2}{*}{ NS } \\
\hline & & Officials & 2.80 & 0.87 & & & & \\
\hline \multirow[t]{2}{*}{3} & \multirow[t]{2}{*}{ Dress making (tailoring) skills training } & Prisoners & 3.22 & 0.76 & \multirow{2}{*}{-0.68} & \multirow{2}{*}{349} & \multirow{2}{*}{0.49} & \multirow{2}{*}{ NS } \\
\hline & & Officials & 3.28 & 0.75 & & & & \\
\hline \multirow[t]{2}{*}{4} & \multirow[t]{2}{*}{ Hair dressing skills training } & Prisoners & 2.64 & 0.86 & \multirow{2}{*}{-0.86} & \multirow{2}{*}{349} & \multirow{2}{*}{0.39} & \multirow{2}{*}{ NS } \\
\hline & & Officials & 2.73 & 0.92 & & & & \\
\hline \multirow[t]{2}{*}{5} & \multirow[t]{2}{*}{ Knitting skills training } & Prisoners & 2.33 & 0.86 & \multirow{2}{*}{-9.15} & \multirow{2}{*}{349} & \multirow{2}{*}{0.00} & \multirow{2}{*}{ S } \\
\hline & & Officials & 3.28 & 0.77 & & & & \\
\hline \multirow[t]{2}{*}{6} & Laundry and dry cleaning services skills & Prisoners & 3.30 & 0.75 & & 340 & 032 & NS \\
\hline & training & Officials & 3.39 & 0.69 & -0.99 & 349 & 0.32 & NS \\
\hline 7 & Metalwork skills training & Prisoners & 3.00 & 0.72 & -234 & 349 & 002 & $S$ \\
\hline & & Officials & 3.21 & 0.79 & -2.34 & 349 & 0.02 & \\
\hline 8 & Soap and pomade making skills training & Prisoners & 2.68 & 0.86 & ? & 340 & 000 & NS \\
\hline & & Officials & 2.68 & 0.80 & -0.02 & 349 & 0.99 & IV \\
\hline & Grand Mean and Standard Deviation & Prisoners & 2.79 & 0.35 & 22 & 340 & 000 & \\
\hline & & Officials & 2.90 & 0.32 & -4.22 & 349 & 0.00 & \\
\hline
\end{tabular}

Key: $\mathrm{N}=$ Number of respondents, $\bar{x}=$ mean, $\mathrm{SD}=$ Standard Deviation, $\mathrm{t}-\mathrm{cal}=\mathrm{t}$ calculated $\mathrm{df}=$ Degree of freedom, Dec. $=$ Decision, NS= No Significant difference and S= Significant difference.

Table 3 above shows that the $\mathrm{t}$-values of $1.20,-1.37,-0.68,-0.86,-9.15,-0.99,-2.34$ and -0.02 with associated probabilities of $0.23,0.17,0.49,0.39,0.00,0.32,0.02$ and 0.99 respectively were obtained. Items $1,2,3,4,6$, and 8 shows that there is no significant difference in the mean responses of the respondents on the extent of participation of prison inmates in vocational skills acquisition programmes for self-reliance and sustainable economic growth in SokotoState. This is because their probability values were greater than 0.05 level of significance. On the other hand, items 5 and 7 shows that there is significant difference between the mean ratings of the prison inmates and officials on the extent to which prison inmates participated in vocational skills acquisition programmes for self-reliance and sustainable economic growth in SokotoState. This is because their probability values were less than 0.05 level of significance. The overall cluster $t$-value of -4.22 with a degree of freedom of 349 and a probability value of 0.00 was also obtained, the null hypothesis was rejected. Thus, there is significant difference between the mean ratings of the prison inmates and officials on the extent to which prison inmates participated in vocational skills acquisition programmes for self-reliance and sustainable economic growth in SokotoState.

\section{Discussion of the Findings}

Findings revealed that the respondents unanimously agreed to a high extent that prison inmates participated in agro-based skills acquisition programme; carpentry and joinery work; dress making (tailoring); hair dressing; knitting; laundry and dry cleaning services; metalwork and soap and pomade making skills acquisition programmes for self-reliance and sustainable economic growth in SokotoState.This is in line with Asokhia and Agbonluae (2013) who affirmed that adult and remedial educational programmes and educational development project are available in some Nigerian prisons.Corroborating with the authors views, Hassan and Oloyede (2011) noted that there is low participation of prison inmates in vocational skills acquisition programmes in Nigerian prisons. The result among others indicated that most of the prison inmates in SokotoState have realized the importance of vocational training, hence their effective participation, bearing in mind that vocational training in prison is not a must for inmates but optional. This finding is in line with 
Onweonye, Obinne and Odu (2013) who succinctly observed that participation of prison inmates in vocational skills acquisition programmes in prison influences them to realise for themselves the importance of work, which can help them to re-enter society after being released. Supporting the above view, Abba (2016) believed that prison inmates prefer attending to vocational education programmes than adult literacy programmes in Nigerian prisons. This view is also in agreement with Agbakwuru and Godfrey (2016) who stated that prison inmates prefer most attending to vocational education programmes than adult literacy programmes in Nigerian prisons.

The findings also revealed that there was significant difference between the mean ratings of prison inmates and prison officials on the extent of participation of prison inmates in vocational skills acquisition programmes for self-reliance and sustainable economic growth in SokotoState. This implies that the null hypothesis which stated that there is no significant difference between the mean ratings of adult prisoners and prison officials on the extent to which prison inmates participated in vocational skills acquisition programmes for self-reliance and sustainable economic growth in SokotoState was rejected. This agrees with Abba and Mbagwu (2016), who testified that prison inmates participated in vocational skills acquisition programmes in Nigerian prisons. It is also in agreement with Abba (2016) who aptly revealed that prison inmates participate in vocational skills acquisition programmes for their rehabilitation in some Nigerian prisons. Therefore, it is believed that Mastery of these identified vocational trade skills would help the prisoners to be rehabilitated and as well become self-employed after their jail term, thereby preventing them from going back into crime as a result of lack of vocational skills. This may in turn lead them to contribute their own quota towards economic growth of the State and the society at large. Mere determination of prison inmates to be law-abiding citizens on discharge without the acquisition of the needed skills by prison inmates may not yield any fruit.

\section{Conclusion}

The study examined the extent to which prison inmates participated in vocational skills acquisition programmes for self-reliance and sustainable economic growth in SokotoState. The sustainable participation of prison inmates in vocational skills acquisition programmes for self-reliance and sustainable economic growth require motivation to the clients. The findings revealed that prison inmates participated in vocational skills acquisition programmes to a high extent for self-reliance and sustainable economic growth in SokotoState. Prison inmates have been identified as inevitable segment of the society that need not be left behind in the current Nigeria's struggle for sustainable economic growth. Any stigmatization against prison inmates by other members of the society as disadvantage group, being problems instead of viewing them as resources, could lead to their low participation in VSA programmes for self-reliance and sustainable economic growth of the society. However, if inmates participate and acquire vocational skills, they can re-enter society as self-reliant citizens. This will enable them contribute their own quota towards sustainable economic growth of the state and the country at large. Based on these findings, the researchers made the following recommendations that:

(1)The Nigerian Prisons Service (NPS) should extend the VSA programmes to other convict and satellite's prisons for self-reliance and sustainable economic growth.

(2) More qualified vocational instructors in various trades should be recruited into Nigeria Prisons Service (NPS) for the training of prisoners in the State and the country at large;

(3) The NPS should introduce more vocational trades that are not available in the prisons. Such as electrical and electronics repairs, graphic arts, shoe making and automobile mechanic skills acquisition programmes while the prison inmates should be encouraged to patronize the programmes for their self-reliance and sustainable economic growth of the society.

\section{Acknowledgements}

The researchers wish to acknowledge Dr. M. A. Yushau, Department of Science and Vocational Education, Usmanu Danfodiyo University, Sokoto, Nigeria and Dr. (Mrs) F. O. Mbagwu Department of Adult Education and Extra-Mural Studies, University of Nigeria, Nsukka who validated the instruments used for the study. The researchers thank the above scholars for their painstaking efforts in scrutinizing the instruments and proof reading the article. Their help and contributions in maintaining the quality of the research work are greatly appreciated.

\section{References}

Abba, M. (2016). Rehabilitation of Prison inmates through Vocational Skills Acquisition Programmes as perceived by prison officials in North - West States, Nigeria: Unpublished PhD Thesis: University of Nigeria, Nsukka, Enugu State, Nigeria.

Abba, M., \& Mbagwu, F. O. (2016). Vocational Skills Training Needs of Prison inmates for Economic Growth in Katsina State, Nigeria. Paper presented at the 2016 National Conference of the Nigeria National Council for Adult Education (NNCAE) held at Alvan Ikoko College of Education, Owerri, Imo State, Nigeria. 
Abba, M., \& Sanda, M. U. (2015).The Effects of Well- planned Correctional Education Programme on the Rehabilitation of Prison inmates, in Nigeria: Journal of Educational Foundations and Development, Benin City: University of Benin, Edo State, Nigeria. 1(1), 13 - 23.

Adewole, O. A. (2012). Effect of Population on Economic development in Nigeria: A qualitative assessment. International journal of physical and social science, 2(5), 1-14.

Asokhia, M. O., \& Agbonluae, O. O. (2013). Assessment of Rehabilitation Services in Nigeria Prisons in Edo State, Nigeria: American Journal of Contemporary Research, 3(1), 140-152.

Agbakwuru, C., \& Godfrey, E. M. I. (2016). Incarceration and the Well-being of Prison Inmates in Nigeria: European Centre for Research, Training and Development. UK (www.eajournals.org).

Dambazau, A. B. (2007). Criminology and Criminal Justice ( $2^{\text {nd }} e d$.). Westerville: Glencoe / McGreaw Hill.

Davis, L. M, Robert, B., \& Jennifer, S. (2016). Corrections-Based Vocational Training Programs: Crime solutions: Santa Monica, National Institute of Justice (NIJ) Report.

Federal Ministry of Interior. (2016). Nigerian Prisons Service: Report: Abuja, Nigeria.

Hassan, M.A, \& Oloyede, T.O. (2013). Evaluation of Component of Adult Education on the Inmates Welfare in Agodi Prison Yard, Ibadan, Oyo States, Nigeria: International Journal of correctional education.

Igbo, E.U.M. (2007). Introduction to Criminology. Nsukka: University of Nigeria Press Ltd.

Nworgwu, B. G. (2015). Educational Research, Basic Issues and Methodology (Second and Enlarged Edition): University Trust Publishers, Nsukka, Enugu State, Nigeria.

Onweonye, C, Obinne, J. I., \& Odu, K. O. (2013).Vocational Training Needs of Prison Inmates in Delta State for Self-reliance. The Global journal of Educational Perspectives: The African Education and Business Research Institute, Inc.1(1).

Okunola, R. (2008). Institutional Treatment and Social Stigma: A Comparative Study of Amanawa Leprosarium and Sokoto Prisons .SokotoState: Faculty of Social Sciences'. A Research Publication, Usmanu Danfodiyo University, Sokoto, SokotoState, Nigeria.

Omoni, G. E., \& Ijeh, S. U. (2009). Qualitative Education for Prisoners: A Panacea to Effective rehabilitation and Integration into the society: Edo Journal of Counselling, 2(1), 28-37

Onisanwa, I. D. (2014). The Impact of Health on Economic growth in Nigeria. Journal of Economics and Sustainable Development, 5(19), 159-166.

Talba, A. M. (2015). Remembering the inmates of Kaduna Prison. Daily Trust News Paper Report, April, 22. Retrieved August, 2015from http://www.dailytrust.com.ng/daily/index.php/feature/52674-rememb...

Tanimu, B. (2010). Nigeria convicts and Prison Rehabilitation ideals: Journal of Sustainable Development in Africa, 12(3), 1-17.

Tenibaije, D. J. T. (2010). Counselling for Productive Employment of Prison Inmate: European journal of Educational Studies, 2(3), $193-202$.

\section{Copyrights}

Copyright for this article is retained by the author(s), with first publication rights granted to the journal.

This is an open-access article distributed under the terms and conditions of the Creative Commons Attribution license (http://creativecommons.org/licenses/by/4.0/). 